\title{
The impact of high-pressure processing on the growth of Photobacterium phosphoreum and biogenic amine formation in marinated herring
}

\section{Yüksek basınç işleminin ringa marinatında Photobacterium phosphoreum gelişimi ve biyojen amin üretimi üzerine etkisi}

\author{
İlknur Uçak ${ }^{1 *}$ • Nalan Gökoğlu² \\ ${ }^{1}$ Nigde Omer Halisdemir University, Faculty of Agricultural Sciences and Technologies, Nigde, Turkey \\ ${ }^{2}$ Akdeniz University, Fisheries Faculty, Antalya, Turkey
}

https://orcid.org/0000-0002-9701-0824

(D) https://orcid.org/0000-0002-7868-1972

Corresponding author: ilknurucak@ohu.edu.tr

Received date: 16.03 .2020

Accepted date: 08.05 .2020

How to cite this paper:

Ucak, I. \& Gokoglu, N. (2020). The impact of high-pressure processing on the growth of Photobacterium phosphoreum and biogenic amine formation in marinated herring. Ege Journal of Fisheries and Aquatic Sciences, 37(4), 363-371. DOI: 10.12714/egejfas.37.4.07

\begin{abstract}
The effects of high-pressure processing (HPP) on Photobacterium phosphoreum growth and biogenic amine formation were evaluated in marinated herring (prepared with $2 \%$ acetic acid $+8 \% \mathrm{NaCl}$; or $4 \%$ acetic acid $+8 \% \mathrm{NaCl}$ solutions). Marinated fish fillets were inoculated with $P$. phosphoreum, vaccum packaged and treated with HPP in different pressure levels (100,300, and $500 \mathrm{MPa}$ ) and pressure holding times (5 and $10 \mathrm{~min}$ ). Control was left as untreated for both marination group. All batches were stored at $4 \pm 1^{\circ} \mathrm{C}$ up to 3 months. The results showed that combined effect of HPP and $4 \%$ acetic acid had much more inhibitory effect on the growth of $P$. phosphoreum, especially pressure levels 300 and $500 \mathrm{MPa}$. During the storage period, $\mathrm{H}_{2} \mathrm{~S}$-producing bacteria growth was not observed in the groups subjected to $500 \mathrm{MPa}$ pressure. Total psychrophilic bacteria did not grow in $500 \mathrm{MPa}$ pressure treated group and $300 \mathrm{MPa} 10 \mathrm{~min}$ pressure treated group prepared with $2 \%$ acetic acid during the storage period. Histamine was detected insignificant levels in the fillets marinated with $4 \%$ acetic acid and treated with HPP. Except for the control group tyramine formation was not found in the samples prepared with $4 \%$ acetic acid. Similarly, putrescine was not found in the samples prepared with $2 \%$ acetic acid and subjected to HPP treatment at the beginning of the storage. Cadaverine levels were found insignificant amount and 300 and $500 \mathrm{MPa}$ pressure treatments suppressed the formation in $4 \%$ acetic acid treated groups compared with $2 \%$ acetic acid treated groups. The results of this study revealed that HPP in combination with $4 \%$ acetic acid had inhibitory effect on $P$. phosphoreum growth and suppressed the formation of histamine, tyramine, putrescine and cadaverine.
\end{abstract}

Keywords: High pressure treatment, Photobacterium phosphoreum, herring, histamine, biogenic amine

Öz: Yüksek hidrostatik basınç işleminin (HPP) ringa marinatında (\%2 asetik asit+\%8 $\mathrm{NaCl}$ ve $\% 4$ asetik asitt $\% 8 \mathrm{NaCl}$ solüsyonları ile hazırlanan) Photobacterium phosphoreum gelişimi ve biyojen amin oluşumu üzerine etkileri değerlendirilmiştir. $P$. phosphoreum ile inoküle edilmiş marine edilmiş balık filetolarına, farklı sürelerde (5 ve $10 \mathrm{dk}$ ) ve farklı düzeylerde (100, 300 ve $500 \mathrm{MPa}$ ) basınç uygulanmıştır. Her iki marinasyon grubunda da kontrol basınç uygulanmadan bırakııııstır. Tüm örnekler $4 \pm 1^{\circ} \mathrm{C}$ 'de 3 ay depolanmışlardır. Sonuçlar, özellikle 300 ve $500 \mathrm{MPa}$ basınç düzeyleri olmak üzere HPP ve $\% 4$ asetik asitin kombine etkisinin $P$. phosphoreum gelişimi üzerine daha fazla inhibitor etkisi olduğunu göstermiştir. Depolama boyunca $500 \mathrm{MPa}$ basınç uygulanan gruplarda $\mathrm{H}_{2} \mathrm{~S}$ üreten bakteri gelişiminin olmadığını gözlenmişstir. \%2 asetik asit ile hazırlanarak $300 \mathrm{MPa}$ 10dk ve $500 \mathrm{MPa}$ basınç uygulanan gruplarda toplam psikrofilik bakterilere depolama süresince gelişememiştir. \%4 asetik asit ile hazırlanan ve HPP uygulanan gruplarda histamine düzeyi önemsiz seviyelerde bulunmuştur. $\% 4$ asetik asitle marine edilen gruplarda kontrol grubu dışında tiramin oluşumu gözlenmemiştir. Benzer şekilde $\% 2$ asetik asitle hazırlanan ve HPP uygulanan gruplarda da depolama başlangııında putresin bulunmamıştır. Kadaverin miktarı önemsiz düzeylerde bulunmuş ve $\% 2$ asetik asit uygulanan gruplara kıyasla \%4 asetik uygulanan gruplarda 300, $500 \mathrm{MPa}$ basınç uygulaması kadaverin oluşumunu baskılamıştır. Bu çalışmanın sonuçları, HPP uygulaması ile \%4 asetik asitin kombine bir şekilde kullanımını $P$. phosphoreum gelişimi ile histamin, tiramin, putresin ve kadaverin oluşumunu baskıladığını göstermektedir.

Anahtar kelimeler Yüksek basınç uygulaması, Photobacterium phosphoreum, ringa, histamine, biyojen amin

\section{INTRODUCTION}

Biogenic amines (BAs) such as histamine (HIM), cadaverine (CAD), putrescine (PUT), tyramine (TYM), spermidine (SPD) and spermine (SPM) are low-molecularweight nitrogenous compounds. BAs are formed by means of decarboxylation of corresponding free amino acids by microorganisms which possess decarboxylase activity. Many bacteria species including enteric bacteria such as Proteus vulgaris, Enterobacter aerogenes, Enterobacter cloacae, Serratia fonticola, Serratia liquefaciens and Citrobacter freundii (Kim et al., 2003; Tsai et al., 2005) are responsible for
BAs formation in seafood. In addition to them, Morganella morganii, Klebsiella pneumoniae, Hafnia alvei and Photobacterium phosphoreum have strong decarboxylase activity.

$P$. phosphoreum is a psychrotrophic and halophilic histamine producing bacteria which has high $\mathrm{CO}_{2}$ resistance (Dalgaard, 2000). BAs formation and spoilage reactions in seafood can be prevented by conventional preservation techniques. However, these techniques such as chilling of seafood to $0-5^{\circ} \mathrm{C}$ are not sufficient alone to inhibit these 
reactions. Therefore, additional preservation methods are required. High pressure processing (HPP) is minimal processing food preservation technologies that depending on the pressure, pressure holding time/temperature and product characteristics allows microbial inactivation at low temperatures with fewer changes in texture, colour and flavour of the product as than the conventional technologies (Ucak et al., 2018). HPP has been employed as a gentle pasteurization technique with generating high quality and microbiologically safe foods. The inactivation mechanism of microorganisms under HPP is based on destruction of membranes and cell walls, denaturation of proteins and enzymes in the cell membrane.

Despite its nutritional value such as high biological value proteins and lipids, fish is highly perishable due to high water activity, high level of unsaturated fatty acids and neutral $\mathrm{pH}$ (Lougovois and Kyrana 2005). The safety consumption of seafood is an important issue which can not be ignored by consumers and there has been increasing interest to extend the shelf-life and improving the microbiological quality.

Previous studies have shown that HPP can inhibit the microbial growth (Reyes et al., 2015; Gudbjornsdottir et al., 2010; Mengden et al., 2015; Kural and Chen, 2008a; Kural et al., 2008b; Kim et al., 2013) and can suppress the BAs formation (Matejkova et al., 2013; Krizek et al., 2014) in fish and fish products. Nevertheless, there are very limited reports on the effects of HPP on inhibition of $P$. phosphoreum and formation of BAs in fish product. Thus, this study was performed to determine the inhibitory effects of HPP on microbial growth and BAs formation in marinated herring storage at $4 \pm 1^{\circ} \mathrm{C}$ for 3 months.

\section{MATERIALS AND METHODS}

\section{Bacterial strain}

Photobacterium phosphoreum (DSM, 15556) were cultured in histidine broth (TSB supplemented with $0.5 \%$ Lhistidine and $2.5 \% \mathrm{NaCl}$ ) at $20^{\circ} \mathrm{C}$ for $2-3$ days. Early stationary phase cells were used and $10^{6} \mathrm{CFU} / \mathrm{mL}$ bacteria cultures were prepared for the inoculation.

\section{Preparation of fish marinade}

Herring (Clupea harengus) fillets were purchased from fish market in Germany (Quakenbrück) and transported in ice boxes to the laboratory of German Institute of Food Technologies. Then fillets were put into polyethylene bags and stored at $-20^{\circ} \mathrm{C}$ until using. For the marination two different solutions were prepared $(2 \%$ acetic acid $(\mathrm{v} / \mathrm{v})+8 \%$ $\mathrm{NaCl}(\mathrm{w} / \mathrm{v})$ and $4 \%$ acetic acid $(\mathrm{v} / \mathrm{v})+8 \% \mathrm{NaCl}(\mathrm{w} / \mathrm{v}))$ in the glass jars. The skins of thawed fish fillets were removed aseptically and rinsed with distilled water. Fish were placed into glass jars as 1:1.5 (w/v) fish-to-solution ratio. The ripening process was performed $4^{\circ} \mathrm{C}$ for 3 days. Marinated fish were removed from the solutions and drained for $30 \mathrm{~min}$ on a sterile bench.

\section{Bacteria inoculation and HPP treatment}

Marinated fillets were dipped into the $P$. phosphoreum culture solution for $5 \mathrm{~min}$. The fish and bacteria solution ratio were $100 \mathrm{~g} / \mathrm{mL}$. The inoculated fillets were vacuum packaged and kept at $2-4^{\circ} \mathrm{C}$ to prevent the temperature effects until the HPP treatment. The vacuum-packed marinated fish were treated with a high-pressure test system (WAVE 6000/55HT; NC Hyperbaric, Burgos, Spain) possessing a 55-L chamber and a maximum pressure level of $600 \mathrm{MPa}$. The pressuretransmitting medium was cold water $\left(10^{\circ} \mathrm{C}\right)$ to maintain temperature conditions at room temperature during HPP treatment. For every $100 \mathrm{MPa}$ increase in the pressure, the adiabatic heating of pressure transmitting fluid was $3-4^{\circ} \mathrm{C}$. The compression and decompression times were not included in the treatment time. 100, 300 and $500 \mathrm{MPa}$ pressure levels were applied for 5 and $10-\mathrm{min}$. Control was left as untreated for each marination group. All samples were stored at $4{ }^{\circ} \mathrm{C}$ for 3 months and periodically evaluated.

\section{Microbiological analysis}

The microbial analyses were performed after HPP treatment and $15,30,45,60,75$ and $90^{\text {th }}$ days of the storage. $10 \mathrm{~g}$ of fish were in a lab blender containing $90 \mathrm{ml}$ pre-chilled sterile peptone physiological saline solution $(0.1 \%$ peptone $(w / v)+0.85 \% \mathrm{NaCl}(w / v))$ for $60 \mathrm{~s}$. Further decimal serial dilutions were prepared from this homogenate in the same chilled sterile diluent. $P$. phosphoreum counts were enumerated by spreading of $0.1 \mathrm{~mL}$ of the sample homogenate onto Long and Hammer agar. Then plates were incubated for 5 days at $15^{\circ} \mathrm{C}$. $\mathrm{H}_{2} \mathrm{~S}$-producing bacteria counts were determined by spreading of $0.1 \mathrm{~mL}$ of the sample homogenate onto Iron agar Lyngby (IA, Atlas 1997). Incubation period was at $15^{\circ} \mathrm{C}$ for 7 days. Black colonies were counted for enumeration. Total pscyhrophilic bacteria enumeration was conducted in Plate Count Agar (PCA) and plates were incubated at $7^{\circ} \mathrm{C}$ for 10 days (ICMSF, 1982).

\section{Biogenic amine analysis}

Ultra Performance Liquid Chromatography (UPLCThermo Scientific, Photodiode Array Detector) was used for the determination of histamine, tyramine, putrescine and cadaverine were conducted according to method of Eerola et al. (1993) with slight modifications. $15 \mathrm{~mL} 0.4 \mathrm{~mol} / \mathrm{L}$ perchloric acid was added to $5.0 \mathrm{~g}$ of fish meat prior to homogenization for $1 \mathrm{~min}$ using an Ultra Turrax T25 (IKA-Labortechnik, Staufen, Germany). The homogenate was centrifuged (10 $\min , 2250 \mathrm{x} \mathrm{g}$ ) and the supernatant passed through a 0.45 $\mu \mathrm{m}$ filter. After, $1 \mathrm{~mL}$ of sample extract was made alkaline by adding $200 \mu \mathrm{L} 2 \mathrm{~mol} / \mathrm{L}$ sodium hydroxide $(\mathrm{NaOH})$ and buffered with $300 \mu \mathrm{L}$ saturated sodium bicarbonate $\left(\mathrm{NaHCO}_{3}\right)$. Then, $1 \mathrm{~mL}$ of dansyl chloride $\left(\mathrm{C}_{12} \mathrm{H}_{12} \mathrm{CINO}_{2} \mathrm{~S}\right)$ solution was added and the reaction mixture was incubated at $40^{\circ} \mathrm{C}$ for $45 \mathrm{~min}$. Residual dansyl chloride was removed by adding $100 \mu \mathrm{L}$ ammonia. After $30 \mathrm{~min}$, mixture was adjusted to $5 \mathrm{~mL}$ with acetonitrile, filtered $(0.45 \mu \mathrm{m}$, PTFE, MS Springer filter) and analyzed. 


\section{Statistical analysis}

All measurements were carried out in triplicate and data were subjected to variance (ANOVA) analysis and Duncan's multiple range tests using the SPSS Version 18.0 statistical package (SPSS Inc., Chicago, IL, USA). A difference was regarded statistically significant at $p<0.05$.

\section{RESULTS AND DISCUSSION}

\section{Effects of HPP on growth of $P$. phosphoreum}

The inhibitory effects of HPP on the viable cell counts of $P$. phosphoreum in marinated herring are given in Figure 1-2. At the beginning the viable cell counts were found as 2.64 , 2.56 and $1.82 \mathrm{log}$ CFU/g in control, $100 \mathrm{MPa} 5 \mathrm{~min}$ and 100 $\mathrm{MPa} 10 \mathrm{~min}$ pressure treated samples marinated with $2 \%$ acetic acid, respectively. $P$. phosphoreum growth was not observed in $300 \mathrm{MPa} 10 \mathrm{~min}$ and $500 \mathrm{MPa} \mathrm{5,} 10 \mathrm{~min}$ pressure treated group untill $60^{\text {th }}$ day of the storage, while bacteria growth was detected at $45^{\text {th }}$ day of the storage in 300 $\mathrm{MPa} 5 \mathrm{~min}$ pressure treated group. Significantly lowest $(p<0.05)$ cell counts were determined in $500 \mathrm{MPa} 5,10 \mathrm{~min}$ pressure treated groups (4.08 and $2.54 \mathrm{log}$ CFU/g) followed by $300 \mathrm{MPa} 10 \mathrm{~min}$ pressure treated samples (5.48 log $\mathrm{CFU} / \mathrm{g}$ ) at the end of the storage period.

In herring fillets marinated with $4 \%$ acetic acid, $P$. phosphoreum could not grow at the beginning of the storage. However, on the $15^{\text {th }}$ day bacteria growth was observed in the control and $100 \mathrm{MPa} 5,10$ min pressure treated groups and at the end reached 6.48, 6.05 and $5.97 \mathrm{log} \mathrm{CFU} / \mathrm{g}$, respectively. Bacteria population did not exceed 7 log CFU/g, which considered as limit value for fish species during the storage period in these groups. Until at the end of the storage period, viable cell counts were not detected in $300 \mathrm{MPa}$ and $500 \mathrm{MPa}$ pressure treated groups. Ruiz-Capillas et al. (2007) reported that HPP treatment does not always inactivate microorganisms completely but may injure a proportion of the population, and the recovery of the injured cells depends on the subsequent conditions.

The findings of present study are consistent with the Kim et al. (2013), reported that $P$. phosphoreum growth was not observed in 300 and $400 \mathrm{MPa}$ pressure treated mackerel muscle. Uçak et al. (2019) found that Morganella psychrotolerans growth was inhibited by $300 \mathrm{MPa}$ and 500 $\mathrm{MPa}$ pressure treatment in marinated herring. The observation of present study pointed out that HPP and $4 \%$ acetic acid combination had more inhibitory effect on the growth of $P$. phosphoreum.

\section{Effects of HPP on $\mathrm{H}_{2} \mathrm{~S}$-producing bacteria}

Total counts of $\mathrm{H}_{2} \mathrm{~S}$-producing bacteria in marinated herring under HPP are represented in Figure 3-4. Initially, viable counts were 2.46 and $2.37 \mathrm{log} \mathrm{CFU} / \mathrm{g}$ in control and $100 \mathrm{MPa} 5$ min pressure treated herring fillets marinated with $2 \%$ acetic acid, respectively. Bacteria growth was detected in $100 \mathrm{MPa} 10 \mathrm{~min}, 300 \mathrm{MPa} 5 \mathrm{~min}$ and $300 \mathrm{MPa} 10 \mathrm{~min}$ pressure treated groups on the $15^{\text {th }}, 45^{\text {th }}$ and $60^{\text {th }}$ day of the storage, respectively. Nevertheless, $\mathrm{H}_{2} \mathrm{~S}$-producing bacteria growth was not recorded in $500 \mathrm{MPa}$ pressure treated groups.

In the fillets marinated with $4 \%$ acetic acid, $\mathrm{H}_{2} \mathrm{~S}$-producing bacteria growth was inhibited in $300 \mathrm{MPa} 10 \mathrm{~min}$ and 500 $\mathrm{MPa}$ pressure treated groups. At the end of the storage period, highest value was observed in control (6.91 log CFU/g), while the lowest $(p<0.05)$ value was found in fillets subjected to $300 \mathrm{MPa} 5 \mathrm{~min}$ pressure level (5.25 log CFU/g). $\mathrm{H}_{2} \mathrm{~S}$-producing bacteria are responsible for the main deterioration in fish and fish products stored at anaerobic conditions. Dalgaard (1993) reported that $\mathrm{H}_{2} \mathrm{~S}$-producing bacteria growth is inhibited by low $\mathrm{pH}$. Herland et al. (2008) determined the $\mathrm{H}_{2} \mathrm{~S}$-producing bacteria in ice stored cod fillet after $9^{\text {th }}$ day of the storage and bacteria cells reached $3.97 \mathrm{log}$ $\mathrm{CFU} / \mathrm{g}$ on the $15^{\text {th }}$ day of the storage.

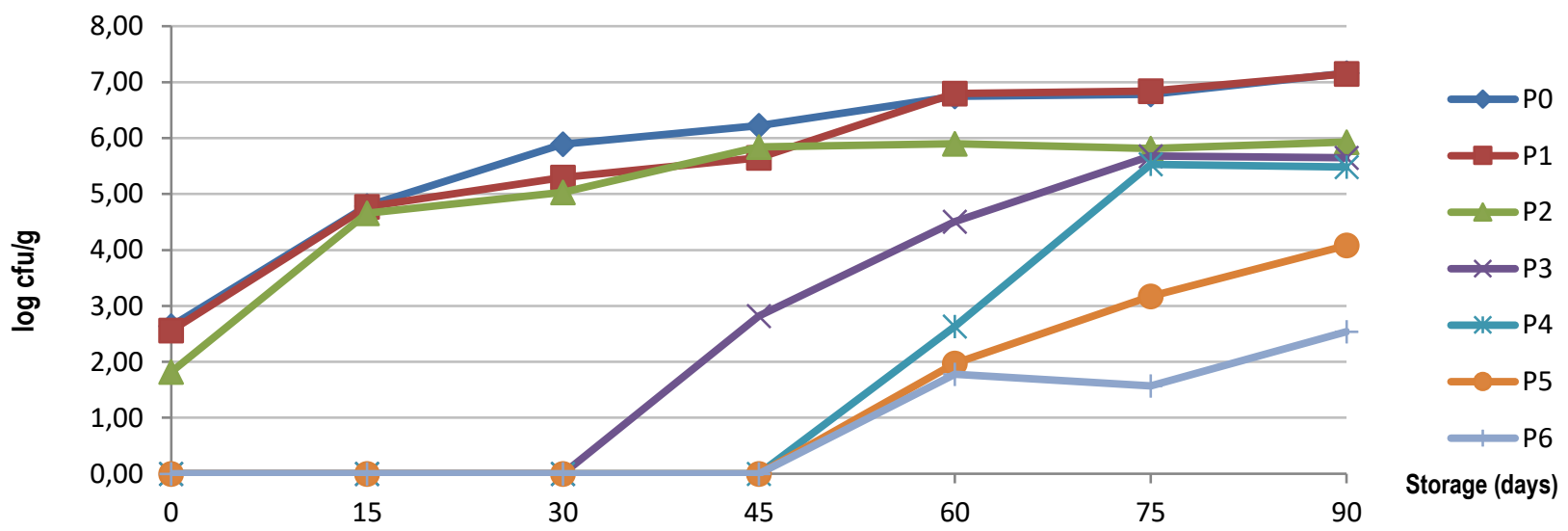

Figure. 1. Effect of HPP on the growth of $P$. phosphoreum in marinated herring prepared with $2 \%$ acetic acid and $8 \% \mathrm{NaCl}$. PO (no HPP treatment), P1 (100 MPa $5 \mathrm{~min}$ ), P2 (100 MPa $10 \mathrm{~min}$ ), P3 (300 MPa $5 \mathrm{~min})$, P4 (300 MPa $10 \mathrm{~min})$, P5 (500 MPa $5 \mathrm{~min})$, P6 (500 $\mathrm{MPa} 10 \mathrm{~min})$ 


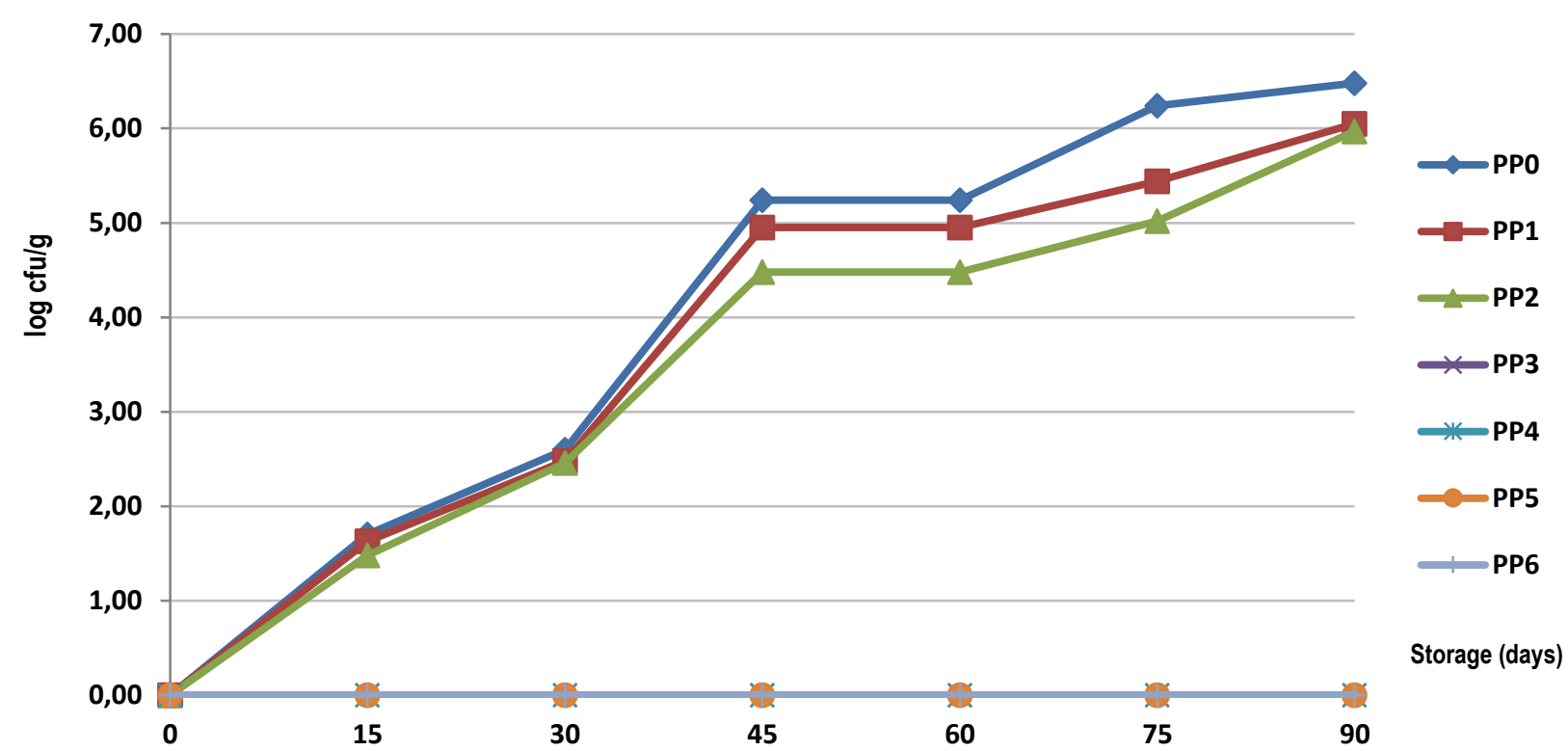

Figure 2. Effect of HPP on the growth of $P$. phosphoreum in marinated herring prepared with $4 \%$ acetic acid and $8 \% \mathrm{NaCl}$. PPO (no HPP treatment), PP1 (100 MPa $5 \mathrm{~min}$ ), PP2 (100 MPa $10 \mathrm{~min}$ ), PP3 (300 MPa $5 \mathrm{~min}$ ), PP4 (300 MPa $10 \mathrm{~min}$ ), PP5 (500 MPa $5 \mathrm{~min})$, PP6 (500 MPa $10 \mathrm{~min}$ )

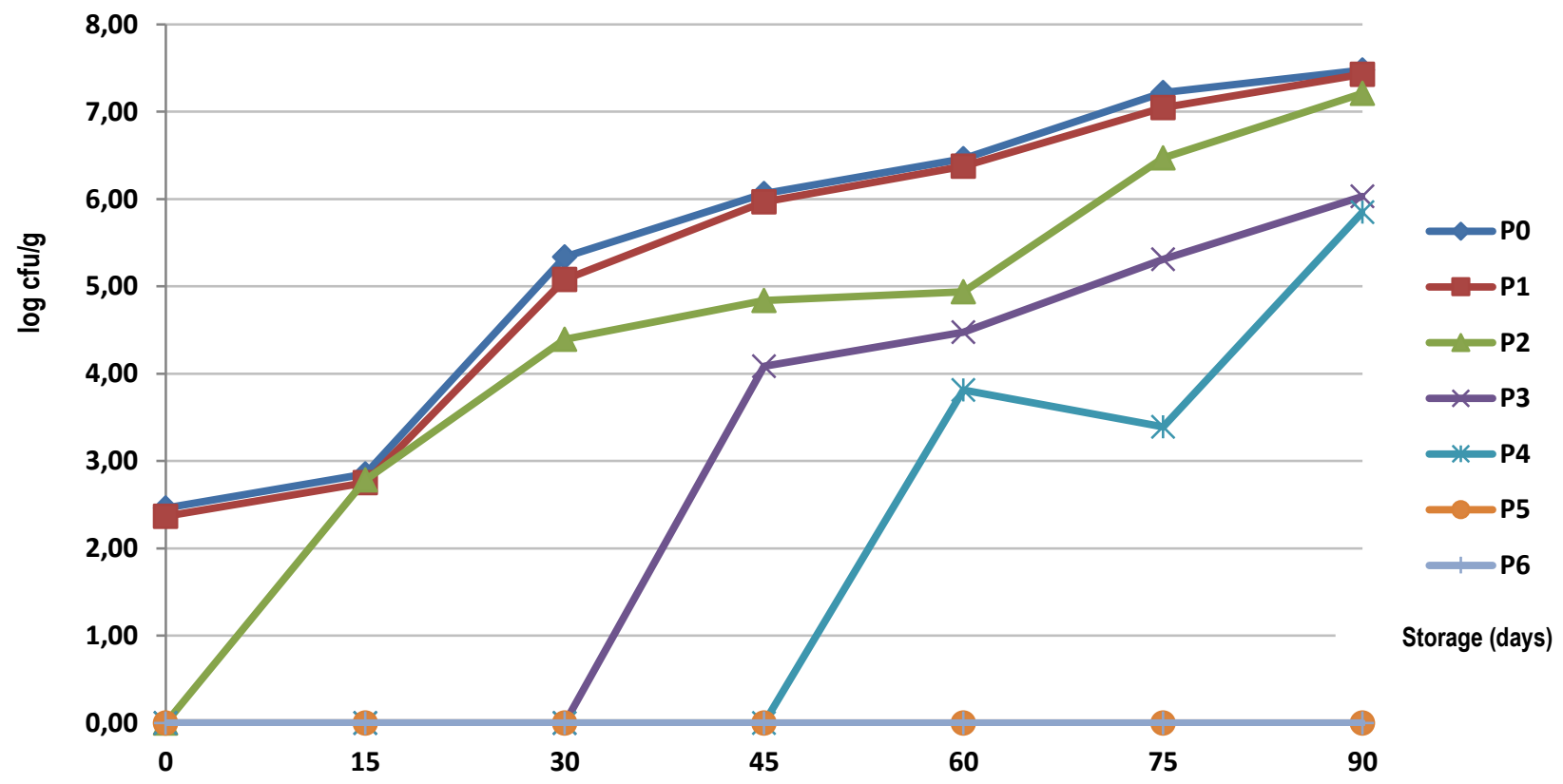

Figure 3. Effect of HPP on $\mathrm{H}_{2} \mathrm{~S}$-producing bacteria growth in marinated herring prepared with $2 \%$ acetic acid and $8 \% \mathrm{NaCl}$. PO (no HPP treatment), P1 (100 MPa $5 \mathrm{~min}$ ), P2 (100 MPa $10 \mathrm{~min})$, P3 (300 MPa $5 \mathrm{~min})$, P4 (300 MPa $10 \mathrm{~min})$, P5 (500 MPa $5 \mathrm{~min})$, P6 (500 $\mathrm{MPa} 10 \mathrm{~min})$ 


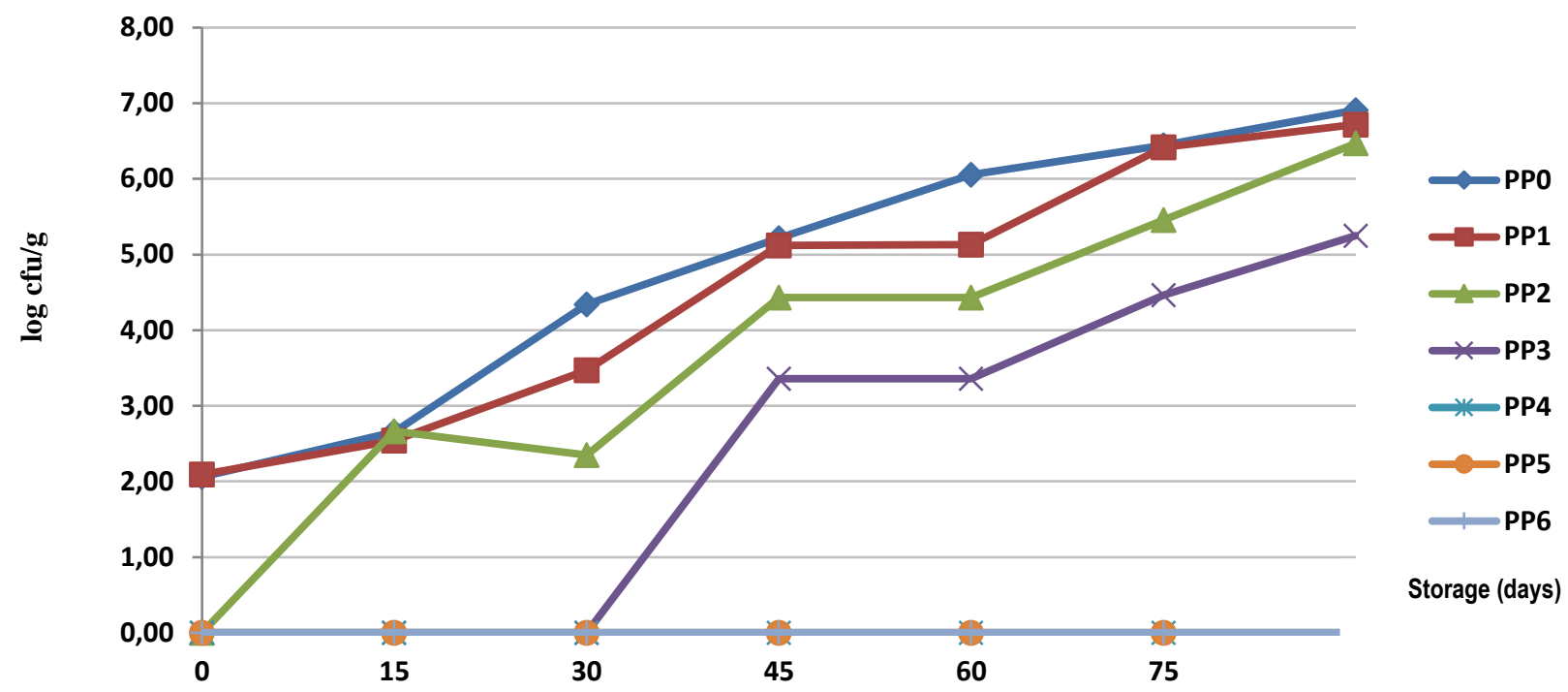

Figure 4. Effect of HPP on $\mathrm{H}_{2} \mathrm{~S}$-producing bacteria growth in marinated herring prepared with $4 \%$ acetic acid and $8 \% \mathrm{NaCl}$. PPO (no HPP treatment), PP1 (100 MPa $5 \mathrm{~min}$ ), PP2 (100 MPa $10 \mathrm{~min}$ ), PP3 (300 MPa $5 \mathrm{~min})$, PP4 (300 MPa $10 \mathrm{~min})$, PP5 (500 MPa $5 \mathrm{~min}$ ), PP6 (500 MPa $10 \mathrm{~min})$

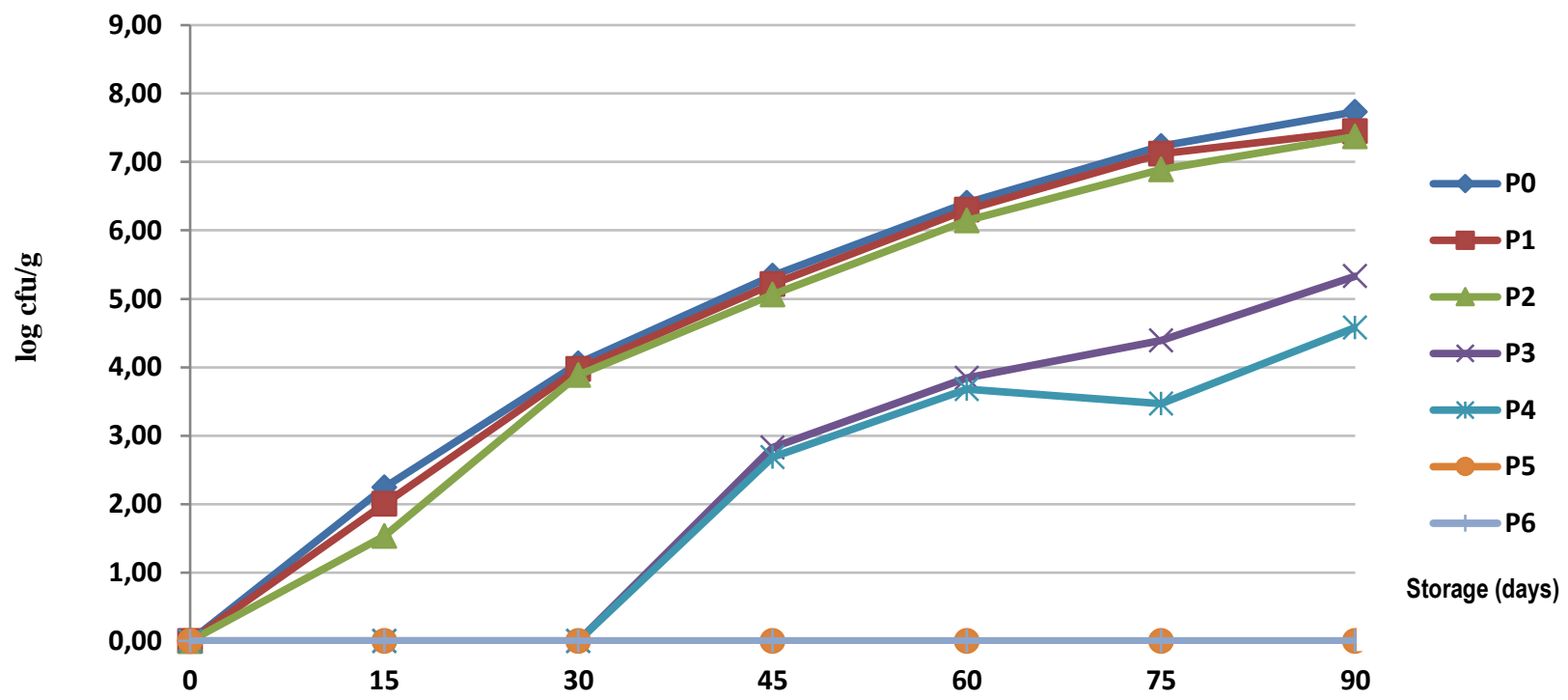

Figure 5. Effect of HPP on total psychrophilic bacteria growth in marinated herring prepared with $2 \%$ acetic acid and $8 \% \mathrm{NaCl}$. PO (no HPP treatment), P1 (100 MPa $5 \mathrm{~min}$ ), P2 (100 MPa $10 \mathrm{~min})$, P3 (300 MPa $5 \mathrm{~min})$, P4 (300 MPa $10 \mathrm{~min})$, P5 (500 MPa $5 \mathrm{~min})$, P6 (500 $\mathrm{MPa} 10 \mathrm{~min})$

\section{Effects of HPP on total psychrophilic bacteria}

Growth of total psychrophilic bacteria counts in marinated herring subjected to HPP are presented in Figure 5-6. In the aerobically stored fresh fish, gram-negative psychrotrophic bacteria are the main groups, causing the spoilage (Ibrahim Sallam, 2007). The initial total psychrophilic bacteria counts were found as 2.46 and $2.37 \log$ CFU/g in control and 100 MPa 5 min pressure treated groups marinated with $2 \%$, while bacteria growth was not observed in $100 \mathrm{MPa} 10 \mathrm{~min}, 500$ $\mathrm{MPa} 5 \mathrm{~min}$ and $300 \mathrm{MPa} 10$ min pressure applied groups until $15^{\text {th }}, 45^{\text {th }}$ and $60^{\text {th }}$ days, respectively. Highest $(p<0.05)$ viable counts were detected in control and $100 \mathrm{MPa}$ pressure treated groups. In the groups subjected to $500 \mathrm{MPa}$ HPP, 
total psychrophilic bacteria growth inhibited during the storage period.

At the beginning of the storage, viable cells were not found in the groups prepared with $4 \%$ acetic acid and subjected to HPP. However, bacteria growth was observed in the control and $100 \mathrm{MPa}$ pressure treated groups. During the storage period, total psychrophilic bacteria growth inhibited in the marinated herring treated with 300 and $500 \mathrm{MPa}$ pressure level. Erkan et al. (2010) reported that total psychrotrophic bacteria count reached at $10^{6} \log \mathrm{CFU} / \mathrm{g}$ at 11 days in the red mullet fillets, while $330 \mathrm{MPa} 5$ min and $220 \mathrm{MPa} 5 \mathrm{~min}$ HPP treated fillets reached this value at 17 and 15 days, respectively. Karim et al. (2011) found the initial total total psychrophilic bacteria count as $10^{4} \mathrm{CFU} / \mathrm{g}$ in herring fillets and it was reported that pressure levels above $200 \mathrm{MPa}$ had inhibitory effects during the storage. In another study Uçak et al. (2019) noticed that $500 \mathrm{MPa}$ pressure treatment inhibited the total psychrophilic bacteria growth in marinated herring inoculated with M. pychrotolerans.

\section{Effects of HPP on the biogenic amine formation}

Histamine (HIM), tyramine (TYM), tryptamine (TRM), putrescine (PUT), and cadaverine (CAD) are the most important BAs in seafood associated with spoilage. Among them HIM and TYM are the most biologically active amines (Shalaby, 1996; Onal, 2007). Table 1-2 represented the effect of HPP treatment on the BAs formation in marinated herring. Initially, HIM level of control sample marinated with $2 \%$ acetic acid was $10.81 \mathrm{mg} / \mathrm{kg}$ and significantly $(\mathrm{p}<0.05)$ increased to $207.36 \mathrm{mg} / \mathrm{kg}$ at the end of the storage. In the HPP treated groups significantly highest $(p<0.05)$ HIM level was observed in $100 \mathrm{MPa}$ pressure treated fillets, while the lowest values were found in the groups subjected to $500 \mathrm{MPa}$ HPP treatment. 4\% acetic acid and HPP combination was more efficient in suppressing the HIM formation. HIM content exceeded the recommended level of $50 \mathrm{mg} / \mathrm{kg}$ by the Food Drug Administration (FDA, 2011) in control and $100 \mathrm{MPa} 5$ min pressure treated fillets marinated with $2 \%$ acetic acid after 30 days. Whereas, HIM was detected insignificant levels in herring fillets marinated with $4 \%$ acetic acid and treated with HPP.

At the beginning TYM levels were 2.27, 1.88 and 0.47 $\mathrm{mg} / \mathrm{kg}$ in control, $100 \mathrm{MPa} 5 \mathrm{~min}$ and $100 \mathrm{MPa} 10 \mathrm{~min}$ pressure treated fillets and marinated with $2 \%$ acetic acid, respectively. TYM level exceeded the suggested acceptable limit for adults (100-800 mg/kg) by Ten Brink et al. (1990) in those groups at $30^{\text {th }}$ day. TYM formation was not observed in $300 \mathrm{MPa}$ and $500 \mathrm{MPa} \mathrm{HPP}$ treated fillets until $30^{\text {th }}$ and $60^{\text {th }}$ days, respectively. Significantly lowest $(p<0.05)$ TYM values were detected in the groups treated with $500 \mathrm{MPa}$ pressure level, while the highest values were observed in the control followed by $100 \mathrm{MPa}$ and $300 \mathrm{MPa}$ pressure treated samples. Except for the control group TYM formation was not found in the samples prepared with $4 \%$ acetic acid. This situation explains that all pressure levels succeded to suppress TYM formation.

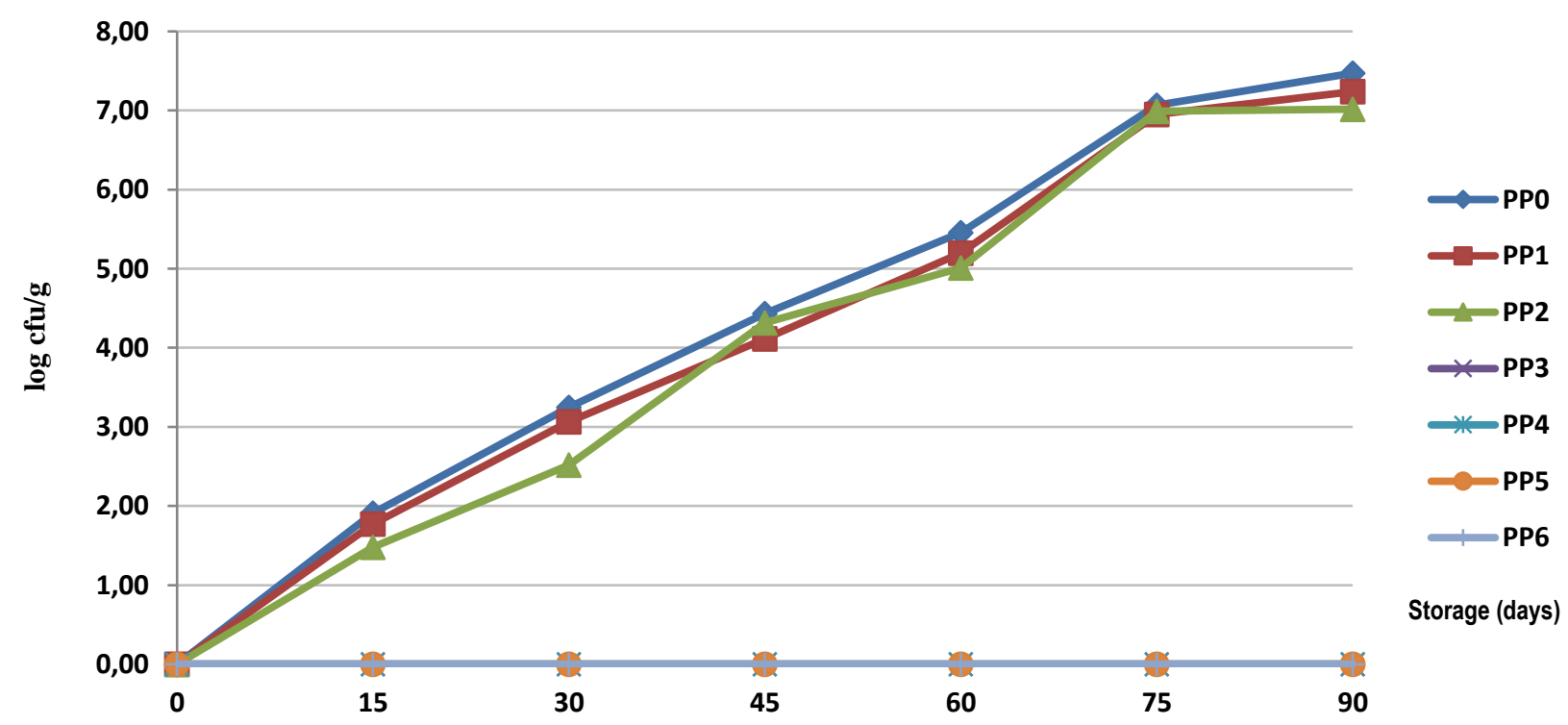

Figure 6. Effect of HPP on total psychrophilic bacteria growth in marinated herring prepared with $4 \%$ acetic acid and $8 \% \mathrm{NaCl}$. PPO (no HPP treatment), PP1 (100 MPa $5 \mathrm{~min}$ ), PP2 (100 MPa $10 \mathrm{~min}$ ), PP3 (300 MPa $5 \mathrm{~min}$ ), PP4 (300 MPa $10 \mathrm{~min}$ ), PP5 (500 MPa $5 \mathrm{~min})$, PP6 (500 MPa $10 \mathrm{~min})$ 
Table 1. Effect of HPP treatment on histamine and tyramine formation in marinated herring during storage $(\mathrm{mg} / 100 \mathrm{~g})$

\begin{tabular}{|c|c|c|c|c|c|c|}
\hline \multirow{2}{*}{$\begin{array}{l}\text { Biogenic } \\
\text { amines }\end{array}$} & \multirow{2}{*}{$\begin{array}{c}\text { Marination } \\
\text { treatment }\end{array}$} & \multirow{2}{*}{ HPP treatment } & \multicolumn{4}{|c|}{ Storage time (days) } \\
\hline & & & 0 & 30 & 60 & 90 \\
\hline \multirow{14}{*}{ Histamine } & \multirow{7}{*}{$2 \%$ acetic acid } & P0 & $10.81 \pm 0.02^{\mathrm{aD}}$ & $25.63 \pm 0.00^{a C}$ & $116.41 \pm 0.07^{\mathrm{aB}}$ & $207.36 \pm 0.00^{\mathrm{aA}}$ \\
\hline & & P1 & $8.54 \pm 0.04 \mathrm{bc}$ & $4.05 \pm 0.01 \mathrm{bD}$ & $110.99 \pm 0.05^{\mathrm{bB}}$ & $163.73 \pm 0.02^{\mathrm{bA}}$ \\
\hline & & $\mathrm{P} 2$ & $7.71 \pm 0.03 c c$ & $5.96 \pm 0.07 \mathrm{CD}$ & $9.51 \pm 0.14 \mathrm{cB}$ & $144.41 \pm 0.05^{c A}$ \\
\hline & & P3 & $4.63 \pm 0.00^{\mathrm{cc}}$ & $3.97 \pm 0.00^{\mathrm{dD}}$ & $7.19 \pm 0.10^{\mathrm{dB}}$ & $22.36 \pm 0.17 \mathrm{bA}$ \\
\hline & & P4 & $6.43 \pm 0.01^{\mathrm{fA}}$ & $3.70 \pm 0.04 \mathrm{eB}$ & $3.68 \pm 0.09 \mathrm{ec}$ & $2.10 \pm 0.08^{\mathrm{eD}}$ \\
\hline & & P5 & $4.73 \pm 0.06^{\mathrm{dA}}$ & $3.10 \pm 0.11^{\mathrm{fB}}$ & $1.90 \pm 0.27^{f C}$ & $0.49 \pm 0.10^{\mathrm{fD}}$ \\
\hline & & P6 & $4.63 \pm 0.13^{\mathrm{eA}}$ & $1.48 \pm 0.13 \mathrm{gB}$ & $0.94 \pm 0.01 \mathrm{gC}$ & $0.45 \pm 0.01 \mathrm{gD}$ \\
\hline & \multirow{7}{*}{$4 \%$ acetic acid } & PPO & $7.50 \pm 0.14^{\mathrm{aB}}$ & $4.74 \pm 0.04 \mathrm{aD}$ & $6.58 \pm 0.11^{\mathrm{ac}}$ & $8.36 \pm 0.03^{\mathrm{eA}}$ \\
\hline & & PP1 & $4.71 \pm 0.05^{b c}$ & $3.39 \pm 0.21 \mathrm{bD}$ & $5.87 \pm 0.05^{\mathrm{bB}}$ & $6.41 \pm 0.01 \mathrm{eA}$ \\
\hline & & PP2 & $2.82 \pm 0.02^{\mathrm{cD}}$ & $2.89 \pm 0.06^{\mathrm{cc}}$ & $3.75 \pm 0.07 \mathrm{cB}$ & $4.82 \pm 0.16 \mathrm{dA}$ \\
\hline & & PP3 & $2.36 \pm 0.01 \mathrm{dA}$ & $2.07 \pm 0.03^{\mathrm{dB}}$ & ND & $0.71 \pm 0.11 \mathrm{dc}$ \\
\hline & & PP4 & $1.95 \pm 0.00^{\mathrm{eA}}$ & $1.58 \pm 0.15^{\mathrm{eB}}$ & ND & $0.71 \pm 0.09 c c$ \\
\hline & & PP5 & $1.10 \pm 0.06^{\mathrm{fB}}$ & $1.21 \pm 0.12^{\mathrm{fA}}$ & ND & ND \\
\hline & & PP6 & $1.11 \pm 0.03 \mathrm{gA}$ & $0.62 \pm 0.09 \mathrm{gB}$ & ND & ND \\
\hline \multirow{14}{*}{ Tyramine } & \multirow{7}{*}{$2 \%$ acetic acid } & P0 & $0.47 \pm 0.05^{\mathrm{cD}}$ & $465.53 \pm 0.17 \mathrm{bA}$ & $462.65 \pm 0.12^{\mathrm{dB}}$ & $382.13 \pm 0.01 \mathrm{eC}$ \\
\hline & & P1 & $2.27 \pm 0.07^{\mathrm{aD}}$ & $450.87 \pm 0.08^{\mathrm{cB}}$ & $508.98 \pm 0.37^{\mathrm{aA}}$ & $410.57 \pm 0.08^{c c}$ \\
\hline & & $\mathrm{P} 2$ & $1.88 \pm 0.27 \mathrm{bD}$ & $469.23 \pm 0.12^{\mathrm{aA}}$ & $437.72 \pm 0.01 \mathrm{eB}$ & $391.08 \pm 0.13^{d C}$ \\
\hline & & P3 & ND & $393.65 \pm 0.20 \mathrm{dC}$ & $541.81 \pm 0.08^{\mathrm{bA}}$ & $480.47 \pm 0.24^{\mathrm{bB}}$ \\
\hline & & P4 & ND & $3.65 \pm 0.13^{\mathrm{eC}}$ & $535.63 \pm 0.03 \mathrm{cA}$ & $509.93 \pm 0.27 \mathrm{aB}$ \\
\hline & & P5 & ND & ND & $1.49 \pm 0.23^{g B}$ & $4.63 \pm 0.05^{\mathrm{fA}}$ \\
\hline & & P6 & ND & ND & $3.20 \pm 0.32^{\mathrm{fA}}$ & $0.87 \pm 0.19 \mathrm{gB}$ \\
\hline & \multirow{7}{*}{$4 \%$ acetic acid } & PPO & ND & $4.48 \pm 0.04 \mathrm{C}$ & $23.36 \pm 0.16^{\mathrm{A}}$ & $20.46 \pm 0.11^{B}$ \\
\hline & & PP1 & ND & ND & ND & ND \\
\hline & & PP2 & ND & ND & ND & ND \\
\hline & & PP3 & ND & ND & ND & ND \\
\hline & & PP4 & ND & ND & ND & ND \\
\hline & & PP5 & ND & ND & ND & ND \\
\hline & & PP6 & ND & ND & ND & ND \\
\hline
\end{tabular}

ND: Not detected; Means indicated by di ferent lowercase letters in the same column differ significantly $(p<0.05)$. Means indicated by different capital letters in the same row differ significantly $(p<0.05)$. Each acetic acid group $(2 \%$ and $4 \%$ ) evaluated in itself.

Table 2. Effect of HPP on putrescine and cadaverine formation in marinated herring during storage $(\mathrm{mg} / 100 \mathrm{~g})$

\begin{tabular}{|c|c|c|c|c|c|c|}
\hline \multirow{2}{*}{ Biogenic amines } & \multirow{2}{*}{$\begin{array}{c}\text { Marination } \\
\text { treatment }\end{array}$} & \multirow{2}{*}{ HPP treatment } & \multicolumn{4}{|c|}{ Storage time (days) } \\
\hline & & & 0 & 30 & 60 & 90 \\
\hline \multirow{14}{*}{ Putrescine } & \multirow{7}{*}{$\begin{array}{l}2 \% \text { acetic } \\
\quad \text { acid }\end{array}$} & P0 & ND & $4.78 \pm 0.17 \mathrm{cc}$ & $12.76 \pm 0.23^{\mathrm{bB}}$ & $13.31 \pm 0.01^{\mathrm{aA}}$ \\
\hline & & $\mathrm{P} 1$ & ND & $3.88 \pm 0.22 \mathrm{dC}$ & $8.73 \pm 0.11 \mathrm{cB}$ & $9.61 \pm 0.08^{\mathrm{cA}}$ \\
\hline & & P2 & ND & $6.31 \pm 0.34 \mathrm{ac}$ & $18.02 \pm 0.32^{\mathrm{aA}}$ & $11.79 \pm 0.18^{\mathrm{bB}}$ \\
\hline & & P3 & ND & $5.65 \pm 0.28 \mathrm{bA}$ & $4.97 \pm 0.02 \mathrm{~d}^{\mathrm{B}}$ & $2.48 \pm 0.29 \mathrm{dC}$ \\
\hline & & P4 & ND & ND & $4.43 \pm 0.08 \mathrm{eA}$ & $1.89 \pm 0.36^{\mathrm{eB}}$ \\
\hline & & P5 & ND & ND & ND & ND \\
\hline & & P6 & ND & ND & ND & ND \\
\hline & \multirow{7}{*}{$\begin{array}{l}4 \% \text { acetic } \\
\text { acid }\end{array}$} & PPO & ND & ND & ND & ND \\
\hline & & PP1 & ND & ND & ND & ND \\
\hline & & PP2 & ND & ND & ND & ND \\
\hline & & PP3 & ND & ND & ND & ND \\
\hline & & PP4 & ND & ND & ND & ND \\
\hline & & PP5 & ND & ND & ND & ND \\
\hline & & PP6 & ND & ND & ND & ND \\
\hline \multirow{14}{*}{ Cadaverine } & \multirow{7}{*}{$\begin{array}{l}2 \% \text { acetic } \\
\quad \text { acid }\end{array}$} & P0 & $13.40 \pm 0.15^{\mathrm{bB}}$ & $7.12 \pm 0.01^{\mathrm{bD}}$ & $10.38 \pm 0.17 \mathrm{cc}$ & $18.14 \pm 0.05^{\mathrm{aA}}$ \\
\hline & & $\mathrm{P} 1$ & $13.05 \pm 0.33^{\mathrm{cB}}$ & $10.82 \pm 0.36^{\mathrm{ac}}$ & $14.81 \pm 0.25^{\mathrm{aA}}$ & $8.23 \pm 0.07 \mathrm{bD}$ \\
\hline & & P2 & $13.45 \pm 0.08^{\mathrm{aA}}$ & $6.00 \pm 0.07^{\mathrm{fB}}$ & $2.19 \pm 0.28^{f C}$ & $1.29 \pm 0.14 \mathrm{CD}$ \\
\hline & & P3 & $11.37 \pm 0.17 \mathrm{dA}$ & $3.99 \pm 0.02^{\mathrm{eC}}$ & $10.98 \pm 0.31 \mathrm{bB}$ & ND \\
\hline & & P4 & $10.91 \pm 0.02^{\mathrm{eA}}$ & $2.77 \pm 0.03 \mathrm{gB}$ & $1.62 \pm 0.07 \mathrm{gc}$ & ND \\
\hline & & P5 & $9.15 \pm 0.06^{\mathrm{fA}}$ & $6.57 \pm 0.09 \mathrm{~dB}$ & $5.45 \pm 0.09 \mathrm{~d} C$ & ND \\
\hline & & P6 & $9.00 \mathrm{gA}$ & $6.36 \pm 0.15^{\mathrm{cB}}$ & $2.09 \pm 0.04 \mathrm{ec}$ & ND \\
\hline & \multirow{7}{*}{$\begin{array}{l}4 \% \text { acetic } \\
\text { acid }\end{array}$} & PPO & $11.56 \pm 0.37 \mathrm{aA}$ & $8.70 \pm 0.05^{\mathrm{aB}}$ & $4.97 \pm 0.46^{\mathrm{aC}}$ & $3.54 \pm 0.02^{\mathrm{aD}}$ \\
\hline & & PP1 & $7.41 \pm 0.26^{\mathrm{dA}}$ & $7.19 \pm 0.28^{\mathrm{dB}}$ & $4.52 \pm 0.15^{\mathrm{cC}}$ & $2.31 \pm 0.06^{\mathrm{fD}}$ \\
\hline & & PP2 & $10.92 \pm 0.18^{\mathrm{bA}}$ & $8.46 \pm 0.16^{\mathrm{cB}}$ & $2.35 \pm 0.27^{f D}$ & $3.13 \pm 0.01 \mathrm{bc}$ \\
\hline & & PP3 & $6.35 \pm 0.06 \mathrm{gA}$ & $5.56 \pm 0.02^{\mathrm{AB}}$ & $2.31 \pm 0.02^{\mathrm{gD}}$ & $3.55 \pm 0.14 \mathrm{ac}$ \\
\hline & & PP4 & $9.31 \pm 0.12^{\mathrm{cA}}$ & $8.49 \pm 0.09 \mathrm{bB}$ & $4.37 \pm 0.09 \mathrm{dc}$ & $2.52 \pm 0.22^{\mathrm{eD}}$ \\
\hline & & PP5 & $6.74 \pm 0.03^{\mathrm{eA}}$ & $5.86 \pm 0.32^{\mathrm{eB}}$ & $4.91 \pm 0.17 \mathrm{bc}$ & $2.67 \pm 0.37 \mathrm{CD}$ \\
\hline & & PP6 & $6.48 \pm 0.42^{\mathrm{fA}}$ & $4.79 \pm 0.252^{\mathrm{gB}}$ & $4.05 \pm 0.13 \mathrm{ec}$ & $2.64 \pm 0.12 \mathrm{dD}$ \\
\hline
\end{tabular}

ND: Not detected; Means indicated by different lowercase letters in the same column differ significantly $(p<0.05)$. Means indicated by different capital letters in the same row differ significantly $(p<0.05)$. Each acetic acid group $(2 \%$ and $4 \%)$ evaluated in itself. 
The inhibitory effects of both $4 \%$ acid concentration and HPP treatment on the PUT formation were clearly visible, since there was no PUT formation in those groups (Table 2). Similarly, PUT was not detected in the samples prepared with $2 \%$ acetic acid and subjected to HPP treatment at the beginning of the storage, however, except for $500 \mathrm{MPa}$ pressure treated groups PUT was observed after 0 day and reached the highest value in control.

CAD formation was found insignificant $(p>0.05)$ levels in all groups during the storage period. The highest CAD level was recorded in both $4 \%$ and $2 \%$ acetic acid treated controls compared with the HPP treated marinated herring fillets, whereas the lowest values were determined in 300 and 500 $\mathrm{MPa}$ pressure treated groups. According to results, $100 \mathrm{MPa}$ HPP treatment did not significantly affected the CAD formation in marinated herring fillets.

The results of the present study are consistent with other studies who reported that $500 \mathrm{MPa}$ pressure treatment is more effective to suppress the PUT and TYM formation (Matejkova et al., 2013; Krizek et al., 2014). Ucak et al. (2019) reported significantly lower HIM formation in the marinated herring and treated with 300 and $500 \mathrm{MPa}$ preesure compared with the control samples. According to another

\section{REFERENCES}

Atlas, R.M. \& Parks, L.C. (1997). Handbook of Microbiologic al Media, 2nd ed. CRC Press, Boca Raton, Florida.

Dalgaard, P. (1993). Evaluation and prediction of microbial fish spoilage. Royal Veterinary

Dalgaard, P. (2000). Fresh and lightly preserved seafood. In C.M.D. Man, \& A.A. Jones (Ed), Shelf life Evaluation of Foods (pp. 110-139). London: Aspen Publishers.

Eerola, S. Hinkkanen, R., Lindfors, E. \& Hirvi, T. (1993). Liquid chromatographic determination of biogenic amines in dry sausages. Journal of AOAC International, 76, 575-577.

Erkan, N. Üretener, G. \& Alpas, H. (2010). Effect of high pressure (HP) on the quality and shelf life of red mullet (Mullus surmelutus). Innovative Food Science and Emerging Technologies, 11, 259-264. DOI:10.1016/j.ifset.2010.01.001

Food and Drug Administration (FDA) (2011). http://www.fda.gov/FoodGuidance

ComplianceRegulatoryInformation/GuidanceDocuments/Seafood/Fishan dFisheriesProductsHazardsandControlsGuide/default.htm (19/08/2019)

Gudbjornsdottir, B. Jonsson, A. Hafsteinsson, H. \& Heinz. (2010). Effect of high-pressure processing on Listeria spp. and on the textural and microstructural properties of cold smoked salmon. LWT - Food Science and Technology, 43, 366-374. DOI:10.1016/j.Iwt.2009.08.015

Herland, H. Esaiassen, M. \& Olsen, R.L. (2008). Muscle Quality and Storage Stability of Farmed Cod (Gadus morhua L.) Compared to Wild Cod. Journal of Aquatic Food Product Technology, 16, 55-66. DOI:10.1300/J030v16n04_06

Ibrahim Sallam, K. (2007). Antimicrobial and antioxidant effects of sodium acetate, sodium lactate, and sodium citrate in refrigerated sliced salmon. Food Control, 18, 566-575. DOI:10.1016/j.foodcont.2006.02.002

ICMSF (1982) Microorganisms in foods. Their significance and methods of enumeration, $2^{\text {nd }}$ edn. London: Univ Toronto Pres.

Karim, N.U. Kennedy, T. Linton, M. Watson, S. Gault, N. \& Patterson M.F. (2011). Effect of high pressure processing on the quality of herring study HPP application significantly inhibited the HDC activity (Kim et al., 2013).

\section{CONCLUSIONS}

BAs can serve as indicators of fish spoilage since their presence in fresh fish is very low. $P$. phosphoreum, which is an important histamine producing bacteria, was inhibited in 300 and $500 \mathrm{MPa}$ pressure treatment. Especially, the high acid concentration and HPP application combination was very efficient in inhibition of bacteria growth. The results of present study showed that the BAs content of marinated herring can noticeably reduced by the application of HPP. $4 \%$ acetic acid and HPP combination was more effective in suppressing the HIM, TYM, PUT and CAD formation.

\section{ACKNOWLEDGEMENTS}

This research was supported by the Scientific and Technological Research Council of Turkey (TUBITAK), Deutscher Akademischer Austauschdienst (DAAD), The Scientific Research Projects Administration Unit of Akdeniz University (project no. FDK-2015-273), management and staff of Deutsches Institut für Lebensmitteltechnik (German Institute of Food Technologies).

(Clupea harengus) and haddock (Melanogrammus aeglefinus) stored on ice. Food Control, 22, 476-484. DOI:10.1016/j.foodcont.2010.09.030

Kim, D.H. Kim, K.B.W. \& Ahn, D.H. (2013). Inhibitory effects of highhydrostatic-pressure treatments on histamine production in mackerel (Scomber japonicus) muscle inoculated with Morganella morganii and Photobacterium phosphoreum. Food Control, 34, 307-311. DOI:10.1016/j.foodcont.2013.04.032

Kim, S.H. Barros-Velazquez, J. Ben-Gigirey, B. Eun, J.B. Jun, S.H. \& Wei, C.I. (2003). Identification of the main bacteria contributing to histamine formation in seafood to ensure product safety. Food Science and Biotechnology, 12, 451-460.

Krizek, M. Matejkova, K. Vacha, F. \& Dadakova, E. (2014). Biogenic amines formation in high-pressure processed pike flesh (Esox lucius) during storage. Food Chemistry, 151, 466-471. DOI:10.1016/j.foodchem.2013.11.094

Kural, A.G. \& Chen, H. (2008a). Conditions for a 5-log reduction of Vibrio vulnificus in oysters through high hydrostatic pressure treatment. International Journal of Food Microbiology, 122, 180-187. DOI:10.1016/j.ijfoodmicro.2007.11.074

Kural, A.G. Shearer, A.E.H. Kingsley, D.H. \& Chen, H. (2008b). Conditions for high pressure inactivation of Vibrio parahaemolyticus in oysters. International Journal of Food Microbiology, 127, 1-5. DOI:10.1016/j.ijfoodmicro.2008.05.003

Lougovois, V.P. \& Kyrana, V.R. (2005). Freshness quality and spoilage of chill-stored fish. Food Policy, Control and Research, 1, 35-86.

Matejkova, K. Krizek, M. Vacha, F. \& Dadakova, E. (2013). Effect of highpressure treatment on biogenic amines formation in vacuum-packed trout flesh (Oncorhynchus mykiss). Food Chemistry, 137, 31-36. DOI:10.1016/j.foodchem.2012.10.011

Mengden, R. Röhner, A. Sudhaus, N. \& Klein, G. (2015). High-pressure processing of mild smoked rainbow trout fillets (Oncorhynchus mykiss) and fresh European catfish fillets (Silurus glanis). Innovative Food Science and Emerging Technologies, 32, 9-15. DOI:10.1016/j.ifset.2015.10.002 
Onal, A. (2007). A review: current analytical methods for the determination of biogenic amines in food. Food Chemistry, 103, 1475-1486. DOI:10.1016/j.foodchem.2006.08.028

Reyes, J.E. Tabilo-Munizaga, G. Perez-Won, M. Maluenda, D. \& Rocob, D. (2015). Effect of high hydrostatic pressure (HHP) treatments on microbiological shelf-life of chilled Chilean jack mackerel (Trachurus murphyi). Innovative Food Science and Emerging Technologies, 29, 107-112. DOI:10.1016/j.jset.2015.01.010

Ruiz-Capillas, C, Colmenero, F.J. Carrascosa, A.V. \& Munoz, R. (2007). Biogenic amine production in Spanish dry-cured "chorizo" sausage treated with high-pressure and kept in chilled storage. Meat Science, 77, 365-371.

DOI:10.1016/j.meatsci.2007.03.027

Shalaby, A.R. (1996). Significance of biogenic amines to food safety and human health. Food Research International, 29, 675-690.
Ten Brink, B. Damirik, C. Joosten, H.M.L.J. \& Huis Veld, H.J. (1990). Occurrence and formation of biologically active amines in foods. International Journal of Food Microbiology, 11, 73-84.

Tsai, Y.H. Lin, C.Y. Chang, S.C. Chen, H.C. Kung, H.F. \& Wei, C.I. (2005). Occurrence of histamine and histamine-forming bacteria in salted mackerel in Taiwan. Food Microbiology, 22, 461-467. DOI:10.1016/j.fm.2004.11.003

Ucak, I. Gokoglu, N. Toepfl, S. \& Galanakis, C.M. (2018). Inhibitory effects of high pressure processing on Photobacterium phosphoreum and Morganella psychrotolerans in vacuum packed herring (Clupea harengus). Journal of Food Safety, 38(6), 1-6. DOl:10.1111/jfs. 12519

Ucak, I. Gokoglu, N. Toepfl, S. Kiessling, M. \& Galanakis, C.M. (2019). Inhibitory effects of high pressure treatment on microbial growth and biogenic amine formation in marinated herring (Clupea harengus) inoculated with Morganella psychrotolerans. LWT- Food Science and Technology, 99, 50-56. DOI:10.1016/j.Iwt.2018.09.058 